\title{
Diel variation in microphytobenthic productivity in areas of different tidal amplitude
}

\author{
A. Miles*, K. Sundbäck \\ Department of Marine Botany, Göteborg University, PO Box 461, 40530 Göteborg, Sweden
}

\begin{abstract}
In situ diel patterns of productivity, total daily productivity $\left({ }^{14} \mathrm{C}\right.$-uptake) and microphytobenthic biomass were measured at 3 sites from different tidal regimes: a shallow subtidal site with negligible tidal fluctuations (Sweden), a shallow subtidal site exposed to distinct salinity and turbidity variations (Italy) and an intertidal site in a macrotidal estuary (Portugal). Measurements were taken at regular intervals ( 5 to 7 ) throughout the period that the sediment was light-exposed and replicated over $3 \mathrm{~d}$. The pattern of diel productivity varied between the sites. The subtidal Swedish site showed the clearest pattern, closely following daily irradiance, while productivity at the Italian subtidal site was influenced by varying freshwater input affecting the turbidity. Daily productivity at the intertidal site was controlled mainly by the tidal exposure patterns, but changes in rates of productivity also occurred across the emersion period. This variation could not be explained purely by irradiance, suggesting the influence of further factors, e. g. nutrient limitation. Despite different sediment type, tidal amplitude and species composition, the biomass and total daily primary productivity at the sites was of the same order of magnitude, suggesting a similar carrying capacity. The main difference between the sites was in the degree of intra-site variation, being greatest for the intertidal site. The relationship between in situ productivity (measured across the diel cycle) and irradiance varied between sites. No relationship could be determined for the highly motile intertidal microphytobenthic community, while a statistically significant relationship between in situ microphytobenthic productivity and irradiance was found at the 2 subtidal sites.
\end{abstract}

KEY WORDS: Primary productivity · Diel variation · Tidal amplitude · Microphytobenthos · Sediments Resale or republication not permitted without written consent of the publisher

\section{INTRODUCTION}

Over the last few decades there has been increased interest regarding the benthic microalgae that inhabit shallow coastal areas and their functional importance in the benthic communities. In addition to providing a substantial source of benthic primary production (for review see Underwood \& Kromkamp 1999), microphytobenthic oxygen production has been shown to influence the chemical and physical properties of coastal sediments, altering the flux of nutrients across the sediment-water interface (Reay et al. 1995, Thornton et al. 1999 and references therein), the chemical gradients

*E-mail: alison.miles@marbot.gu.se within the sediment (Revsbech et al. 1988, Lorenzen et al. 1998), and sediment denitrification (RisgaardPetersen et al. 1994, Rysgaard et al. 1995). Furthermore, microphytobenthos affects sediment stability through exopolymer production, a secondary product of photosynthesis (carbohydrate) (Paterson 1989, Sutherland et al. 1998 and references therein).

Despite the recognition of the importance of these primary producers, their contribution to the budgets of the productivity of shallow, coastal sediments has proved to be difficult to assess. While general methods for estimating phytoplankton productivity are well established, making comparisons between different geographical areas possible, this is not yet the case for the microphytobenthos. One obvious reason for this is the complex, highly stratified environments that these 
phototrophs inhabit and the migratory behaviour of the communities themselves, particularly evident in intertidal habitats (Happey-Wood \& Jones 1988, Pinckney et al. 1994, Serôdio et al. 1997). As a result, to obtain realistic estimations of microphytobenthic productivity it is necessary to carry out measurements in intact sediment. To date, however, our quantitative knowledge of microphytobenthic productivity and the factors controlling it are based on a series of highly varying techniques, including both sediment slurries and intact sediment cores, in situ and laboratory measurements, as well as varying depths of sediment samples (see tables in Colijn \& de Jonge 1984, MacIntyre et al. 1996).

One factor that has been suggested to locally influence the spatial abundance and primary productivity of microphytobenthos, e.g. within an estuary, is the sediment type (Underwood \& Kromkamp 1999 and references therein). Sediment type, which is a result of physical processes, determines the fraction of the algal community that is motile and hence able to migrate vertically. While motile 'epipelic' diatoms dominate in the finer, muddier sediments, typical of tidal mudflats, non-migrating, 'epipsammic' microalgae (mainly diatoms and cyanobacteria attached to the sand grains) often dominate in sandier sediments. On a larger geographical scale, a major factor that could be assumed to influence the behaviour of the microphytobenthos is the tidal amplitude. On intertidal mudflats, the algal communities are subjected to regularly alternating periods of air exposure and turbid submersion periods, while in subtidal and microtidal or non-tidal conditions, the water column is often clear, enabling photosynthesis throughout the daylight period. Measurements of microphytobenthic production in intact sediments have been carried out in both subtidal and intertidal habitats, but studies have incorporated a wide range of methods. These have included oxygen exchange (e.g. Shaffer \& Onuf 1985, Brotas \& Catarino 1995), ${ }^{14}$ C uptake (Sundbäck et al. 1996, Hartig et al. 1998), oxygen microelectrodes (Revsbech \& Jørgensen 1983, Pinckney \& Zingmark 1991, 1993) and, more recently, pulse-amplitude-modulated fluorometry (PAM) (Hartig et al. 1998, Kromkamp et al. 1998, Serôdio 1999). Consequently, comparisons on a larger geographical scale, e.g. between different climate and tidal areas, have been impossible as the methods measure different aspects of primary production.

To our knowledge no one study has set out to directly evaluate in situ productivity in coastal areas from different tidal regimes using a single method. The objective of this work was to assess, using an in situ ${ }^{14} \mathrm{C}$-technique, the daily pattern of productivity and microphytobenthic biomass and total daily production from different tidal regimes at differing geographical locations. Replication on a daily basis was included at each site, as this important level of temporal replication (Morrisey et al. 1994) is often overlooked. Sites studied were (1) a shallow subtidal site with negligible tidal fluctuations, (2) a shallow subtidal site in a microtidal area exposed to distinct fluctuations of e.g. salinity and nutrients in the overlying water, and (3) an intertidal site in a macrotidal estuary.

\section{MATERIALS AND METHODS}

Study sites. Diel variation in benthic microalgal productivity was measured at 3 sites from different tidal regimes by ${ }^{14} \mathrm{C}$ uptake in intact sediment cores. One intertidal site (Sarilhos Pequenos, Tagus Estuary, Portugal: $38^{\circ} 41^{\prime} \mathrm{N}, 8^{\circ} 59^{\prime} \mathrm{W}$ ) and 2 shallow subtidal sites (Giralda, Sacca di Goro, Italy: $44^{\circ} 50^{\prime} \mathrm{N}, 12^{\circ} 16^{\prime} \mathrm{E}$, and Vallda, Kattegat, Sweden: $57^{\circ} 29^{\prime} \mathrm{N}, 10^{\circ} 56^{\prime} \mathrm{E}$ ) were studied. One of the subtidal sites, Giralda, was strongly influenced by the tidal cycle. The sites represented different sediment environments with a widespread geographical location within the temperate zone. Site characteristics and sampling regimes are shown in Table 1.

Giralda is located in the western corner of the Sacca di Goro lagoon in the Adriatic Sea, close to the freshwater inlet of the Po di Volano canal. The incoming tide (tidal range 0.3 to $0.9 \mathrm{~m}$ ) dilutes nutrients in the river water, resulting in large salinity and nutrient variations in the water column (Bartoli et al. 1996). Vallda is a shallow brackish-water bay on the west coast of Sweden, at the transition of the Kattegat and Skagerrak, an area where the tidal amplitude is only 0.1 to $0.2 \mathrm{~m}$ (Sundbäck et al. 2000). The Tagus Estuary is a large, shallow macrotidal estuary with a tidal amplitude that ranges from $<1$ to $4 \mathrm{~m}$ during a spring-neap cycle (Brotas et al. 1995). The general nutrient status of the 3 areas is different, and can be indicated by the annual maximum concentrations of nitrate in the overlying water: Sacca di Goro is affected by freshwater runoff, with maximum $\mathrm{NO}_{3}$ concentrations of ca $150 \mu \mathrm{M}$, Vallda is a low-nitrogen area with peak values of $\mathrm{NO}_{3}<10 \mu \mathrm{M}$, while $\mathrm{NO}_{3}$ in the Tagus estuary reaches values of ca $200 \mu \mathrm{M}$ (Dalsgaard 1998).

Sampling design. Measurements were made in April/May at Giralda, in June at Sarilhos Pequenos, and in August at Vallda, when daylength and irradiance levels could be considered approximately equivalent between sites. Primary productivity $(\mathrm{P})$ was measured in situ at evenly spaced intervals throughout periods that the sediment surface was light-exposed (i.e. throughout the daytime period for the subtidal sites and throughout the daytime emersion period for the intertidal site). At each site, measurements were 
Table 1. Sites, sampling periods and incubation details for microphytobenthic productivity measurements. Nutrient concentrations are means $\pm \mathrm{SE}$

\begin{tabular}{|c|c|c|c|c|c|c|c|}
\hline $\begin{array}{l}\text { Site } \\
\text { (latitude/ } \\
\text { longitude) }\end{array}$ & $\begin{array}{l}\text { Substratum, } \\
\text { tidal regime, } \\
\text { water depth }(\mathrm{m})\end{array}$ & $\begin{array}{l}\text { Sampling } \\
\text { dates } \\
(1998)\end{array}$ & $\begin{array}{c}\mathrm{NH}_{4} \text { in overlying } \\
\text { water } \\
\left(\mu \mathrm{mol}^{-1}\right)\end{array}$ & $\begin{array}{c}\mathrm{NO}_{3} \text { in overlying } \\
\text { water } \\
\left(\mu \mathrm{mol} \mathrm{l} l^{-1}\right)\end{array}$ & $\begin{array}{l}\text { Labelling } \\
\text { method }\end{array}$ & $\begin{array}{c}\text { No. of }{ }^{14} \mathrm{C} \\
\text { incubations } \\
\mathrm{d}^{-1}\end{array}$ & $\begin{array}{c}\text { No. of cores } \\
\text { (light/dark) } \\
\text { for each } \\
\text { incubation }\end{array}$ \\
\hline Giralda & Sand, & 29 Apr & 34.27 & 24.30 & \multirow[t]{3}{*}{ Percolation } & \multirow[t]{3}{*}{6} & \multirow[t]{3}{*}{$4 / 2$} \\
\hline Sacca di Gorro & Subtidal, & 02 May & \pm 2.17 & \pm 1.69 & & & \\
\hline $\begin{array}{l}\text { Italy } \\
\left(44^{\circ} 50^{\prime} \mathrm{N}, 12^{\circ} 16^{\prime} \mathrm{E}\right)\end{array}$ & Е) $\quad 0.3-0.9$ & 05 May & $(\mathrm{n}=11)$ & $(\mathrm{n}=11)$ & & & \\
\hline Vallda & Sand, & 19 Aug & 0.36 & 0.6 & \multirow[t]{3}{*}{ Percolation } & \multirow[t]{3}{*}{7} & \multirow[t]{3}{*}{$5 / 2$} \\
\hline Kattegat & Subtidal, & 24 Aug & \pm 0.25 & \pm 0.45 & & & \\
\hline $\begin{array}{l}\text { Sweden } \\
\left(57^{\circ} 29^{\prime} \mathrm{N}, 10^{\circ} 56^{\prime} \mathrm{E}\right)\end{array}$ & Е) $0.1-0.3$ & 26 Aug & $(\mathrm{n}=3)$ & $(\mathrm{n}=3)$ & & & \\
\hline Sarilhos Pequenos & Mud, & 17 Jun & 30.82 & 34.79 & \multirow[t]{3}{*}{ Diffusion } & \multirow[t]{3}{*}{$4-5$} & \multirow[t]{3}{*}{$5 / 2$} \\
\hline Tagus Estuary & Intertidal & 23 Jun & \pm 10.37 & \pm 1.84 & & & \\
\hline $\begin{array}{l}\text { Portugal } \\
\qquad\left(38^{\circ} 41^{\prime} \mathrm{N}, 8^{\circ} 59^{\prime} \mathrm{W}\right)\end{array}$ & & 25 Jun & $(\mathrm{n}=3)$ & $(\mathrm{n}=3)$ & & & \\
\hline
\end{tabular}

repeated on 3 separate days. Sampling regimes, number of cores, length and timing of the incubations are shown in Table 1.

Primary productivity. At each sampling period, 6 or 7 sediment cores (including 2 dark cores which were used to correct for dark ${ }^{14} \mathrm{C}$-uptake) were taken with 'Jönsson tubes' (i.d. $44 \mathrm{~mm}$ ), enabling percolation of the radiolabel into undisrupted sediment (for more specifications see Jönsson 1991). For the subtidal sites (sandy sediment), the sediment cores were collected and moved to the shore for the ${ }^{14} \mathrm{C}$ addition. $150 \mu \mathrm{l}$ of ${ }^{14} \mathrm{C}$ bicarbonate $(=3 \mu \mathrm{Ci})$ were added to the water space (ca $40 \mathrm{ml}$ ). The water was carefully mixed and the labelled water was then percolated through the top $5 \mathrm{~mm}$ of the sediment (estimated to include the photosynthetically active zone). The cores were completely sealed with clear Perspex lids and then placed back in the sampled area so that they received in situ irradiance. Cores were incubated for ca $1 \mathrm{~h}$. At the end of the incubation, a $2 \mathrm{ml}$ cut-off syringe was used to core the surface $5 \mathrm{~mm}$ of sediment. Carbon incorporation was stopped by adding 5 drops of $0.1 \mathrm{M} \mathrm{HCl}$, which removed the unincorporated inorganic carbon. Samples were then dried at ca $40^{\circ} \mathrm{C}$, and stored prior to the addition of $10 \mathrm{ml}$ scintillation fluid (Hionic Fluor ${ }^{\mathrm{TM}}$, Packard). Samples were analysed on a Beckman LS 3801 scintillation counter including quenching correction. Total $\mathrm{CO}_{2}$ concentration and carbon assimilation were calculated according to Ærtebjerg Nielsen \& Bresta (1984).

For the intertidal site, it was necessary to modify the method as (1) it was impossible to percolate the label through the cohesive sediment, (2) for intertidal areas it is unrealistic for the sediments to stand with a substantial amount of overlying water during the emersion period, and (3) excessive movement of the sediment cores resulted in rapid movement of motile cells from the sediment surface (and euphotic zone). Cores were therefore pushed into the sediment and labelled in situ by dropping $2 \mathrm{ml}$ of labelled ( $3 \mu \mathrm{Ci}$ ) water onto the sediment surface. Earlier observation indicated that this did not disturb the sediment surface as there was no obvious migration of the microphytobenthos from the surface caused by such addition. The accumulation of the microalgal cells at the sediment-air interface during the emersion period (photosynthetically active layer <250 $\mathrm{mm}, \mathrm{N}$. Risgaard-Petersen pers. comm.) indicated that diffusion of the label alone was sufficient to introduce the label into the photosynthetically active layer. Earlier estimation of the evaporation rate from the sediment surface $\left(1 \mathrm{~mm} \mathrm{~h}^{-1}, \mathrm{~N}\right.$. RisgaardPetersen pers. comm.) indicated that loss of label to the air was negligible. Following the incubation period, samples were treated as described for the subtidal samples.

For biomass-specific productivity, rates were normalised to the mean chlorophyll a ( $\mathrm{chl}$ a) concentration (see below) for each period, as biomass estimates and production rates were measured on different cores. Daily production was calculated by summing the hourly rates measured over the light-exposed periods. Where the hourly rate was not measured, a mean of the 2 adjacent measurements was taken.

Chlorophyll a (biomass estimation). At each time period, 5 sediment cores, collected from the same area as the productivity cores, were sampled with a cut-off $20 \mathrm{ml}$ syringe and then sub-sectioned to obtain the top $3 \mathrm{~mm}$ of the sediment. This sediment was frozen and then freeze-dried. Chl $a$ in the samples was analysed on a Shimadzu UV-visible recording spectrophotometer after a $24 \mathrm{~h}$ extraction of pigments with $90 \%$ acetone (Lorenzen 1967). 
Species composition. Sediment samples $(5 \mathrm{~mm}$ deep) were taken with a syringe corer (i.d. $8.7 \mathrm{~mm}$ ). To obtain a rough indication of the species composition at the different sites, counts of the first 100 living cells encountered were made using an epifluorescence microscope.

Overlying water. Samples of overlying water for nutrient analysis were taken in situ with $50 \mathrm{ml}$ disposable syringes and filtered into $5 \mathrm{ml}$ disposable plastic vials through cellulose acetate syringe filters (Sartorius, pore size $0.45 \mu \mathrm{m})$. Inorganic nitrogen $\left(\mathrm{NO}_{3}+\right.$ $\mathrm{NO}_{2}, \mathrm{NH}_{4}$ ) were analysed on a TRAACS 800 autoanalyser (Braun \& Lubbe) using standard colorimetric methods (Grasshoff et al. 1983).

Physical parameters. Photosynthetically available radiation (PAR) was measured with a quantum sensor LI 190SA connected to a LiCor Data Logger LI-1000 for the Giralda and Sarilhos Pequenos sites. Data were integrated every $15 \mathrm{~min}$. At Vallda, PAR was measured with a scalar irradiance sensor (Biospherical Instruments) at approx. 5 min intervals during the sampling period. As an underwater light sensor was not available, irradiance measurements made were of incident irradiance in the air. At Vallda it was possible to use a light attenuation coefficient to estimate PAR at the sediment surface. At Giralda, however, this type of correction proved impossible due to the varying turbidity in the water column during the diel period. Temperature, salinity (Acto refractometer) and pH (Metrohm 704 portable $\mathrm{pH}$ meter) were recorded throughout the experimental periods. For the subtidal sites, the depth of the water column was measured at each incubation period. Grain-size distribution of the sediment was analysed by dry-sieving.

Data analyses. Differences between time periods were tested using 1-way ANOVA, followed by Student-Newman-Keuls (SNK) pairwise comparisons, with time as the factor. Homogeneity of variances was

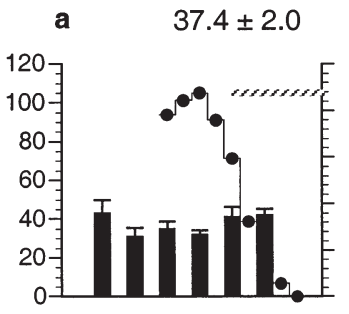

$32.0 \pm 3.3$

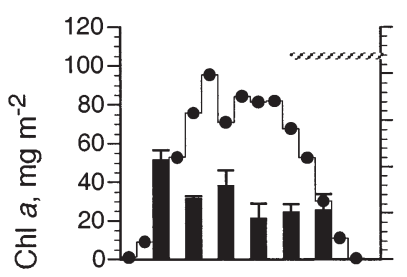

$28.2 \pm 3.0$

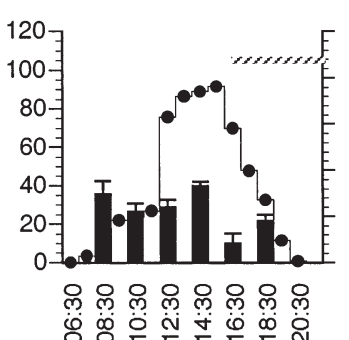

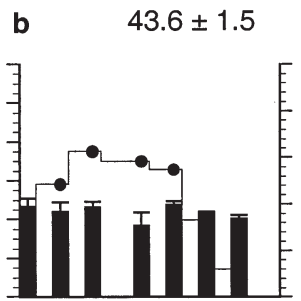

$52.8 \pm 1.7$

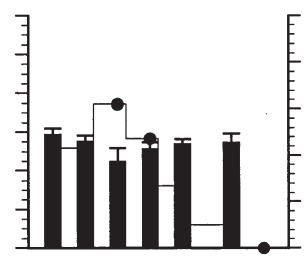

$45.8 \pm 1.7$

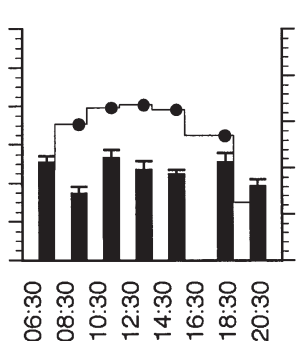

Time of day

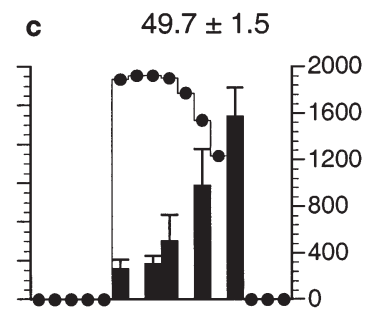

$25.7 \pm 3.1$

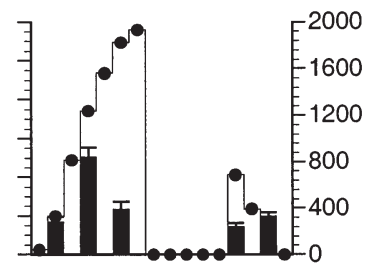

$30.7 \pm 4.0$

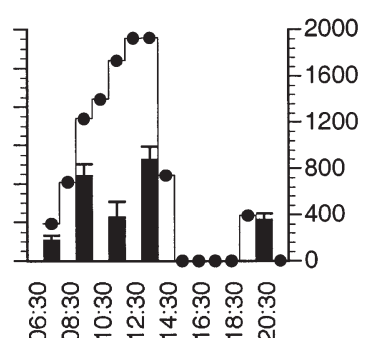

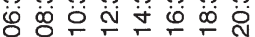

Fig. 1. Mean microphytobenthic biomass estimated as chlorophyll a at (a) Giralda (29 April, 2 and 5 May), (b) Vallda (19, 24 and 26 August), and (c) Sarilhos Pequenos (17, 23, and 25 June): days are shown in chronological order from top to bottom. Bars: \pm SE for each incubation period $(n=5)$; values: means \pm SE for each incubation day ( $n=25$ to 35$)$. Right-hand ordinate: irradiance ( $\bullet)$ in air for Giralda (a) and at sediment surface for Vallda (b) and Sarilhos Pequenos (c). Here, and in subsequent figures, hatched diagonal stripes at top right of graphs indicate periods of turbidity in the water column at Giralda 
tested using Cochran's test and the data were transformed according to Underwood (1997) when variances were found to be heterogeneous. Differences were accepted as significant at $\mathrm{p}<0.05$.

\section{RESULTS}

\section{Diel variation within sites}

Giralda, Italy: subtidal site, strong tidal influence

The turbidity of the water during each diel period varied greatly due to the changes in freshwater input and associated levels of suspended matter throughout the tidal cycle. Although the irradiance measurements shown in Figs. 1a, 2a \& 3a were measured in the air, the periods of turbid water (sediment surface not visible) are indicated. The salinity of the overlying water ranged from 5 to 20 (Fig. 2), and the temperature of the incubated sediment from 15 to $23^{\circ} \mathrm{C}$.

Chl a varied between 8 and $58 \mathrm{mg}$ chl a m${ }^{-2}$, but no differences were found between time blocks or days ( $p>0.05, n=17$ to 18 ) (Fig. 1a). Mean hourly productivity ranged from 1 to $40 \mathrm{mg} \mathrm{C} \mathrm{m}^{-2} \mathrm{~h}^{-1}(\mathrm{n}=4)$, with means, when averaged over the separate days $\left(\mathrm{P}_{\mathrm{D}}\right)$, decreasing over the sampling period (Fig. 2a). The drop in productivity on 5 May could have resulted from the large amount of rainfall over the previous 2 to $3 \mathrm{~d}$, which increased the freshwater runoff, and subsequently the turbidity, in the area (see salinity variation in Fig. 2a). The effect of this can be seen by summing production over the daylight period for the $3 \mathrm{~d}$, which gave similar values for 29 April and 2 May (260 and $253 \mathrm{mg} \mathrm{C} \mathrm{m}^{-2}$ $\mathrm{d}^{-1}$, respectively) but dropped by over $50 \%$ on 5 May (115 mg C m-2 $\mathrm{d}^{-1}$ ). Time blocks were significantly different on all $3 \mathrm{~d}$ for both $\mathrm{P}$ and biomass-specific productivity $\left(\mathrm{P}^{\mathrm{B}}\right)(\mathrm{p}<0.005)$. Maximal rates of $\mathrm{P}$ were recorded
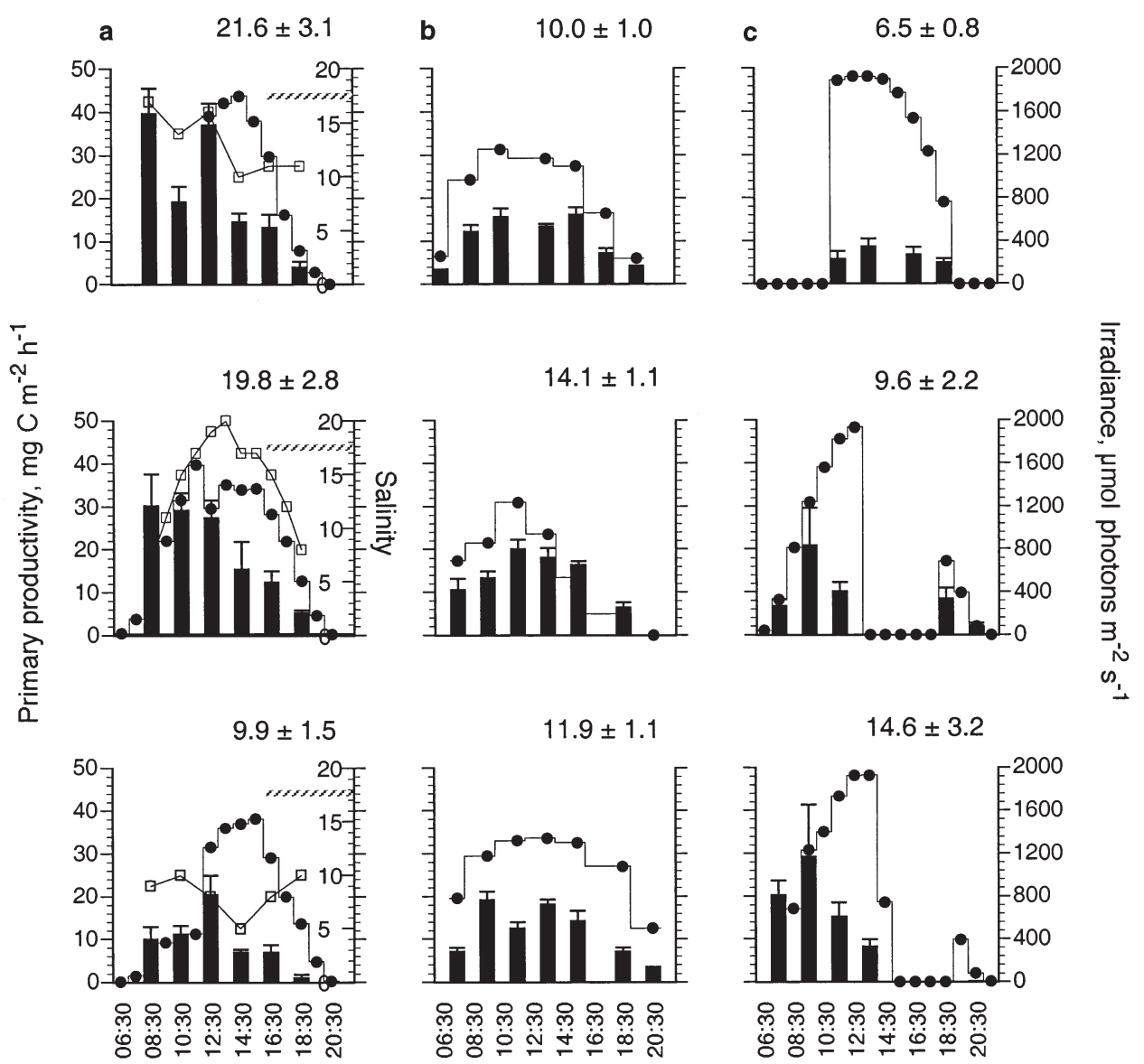

Time of day

Fig. 2. Mean primary productivity (as ${ }^{14} \mathrm{C}$ uptake) at (a) Giralda, (b) Vallda, and (c) Sarilhos Pequenos: days (see Fig. 1 legend) are shown in chronological order from top to bottom. Bars: \pm SE for each incubation period ( $n=4$ to 5$)$; values: means \pm SE averaged over each day ( $\mathrm{n}=20$ to 35 ). Right-hand ordinate: irradiance ( $\bullet$ ) in air for Giralda (a) and at sediment surface for Vallda

(b) and Sarilhos Pequenos (c). Salinity of overlying water at Giralda is also shown ( $\square$ ) 


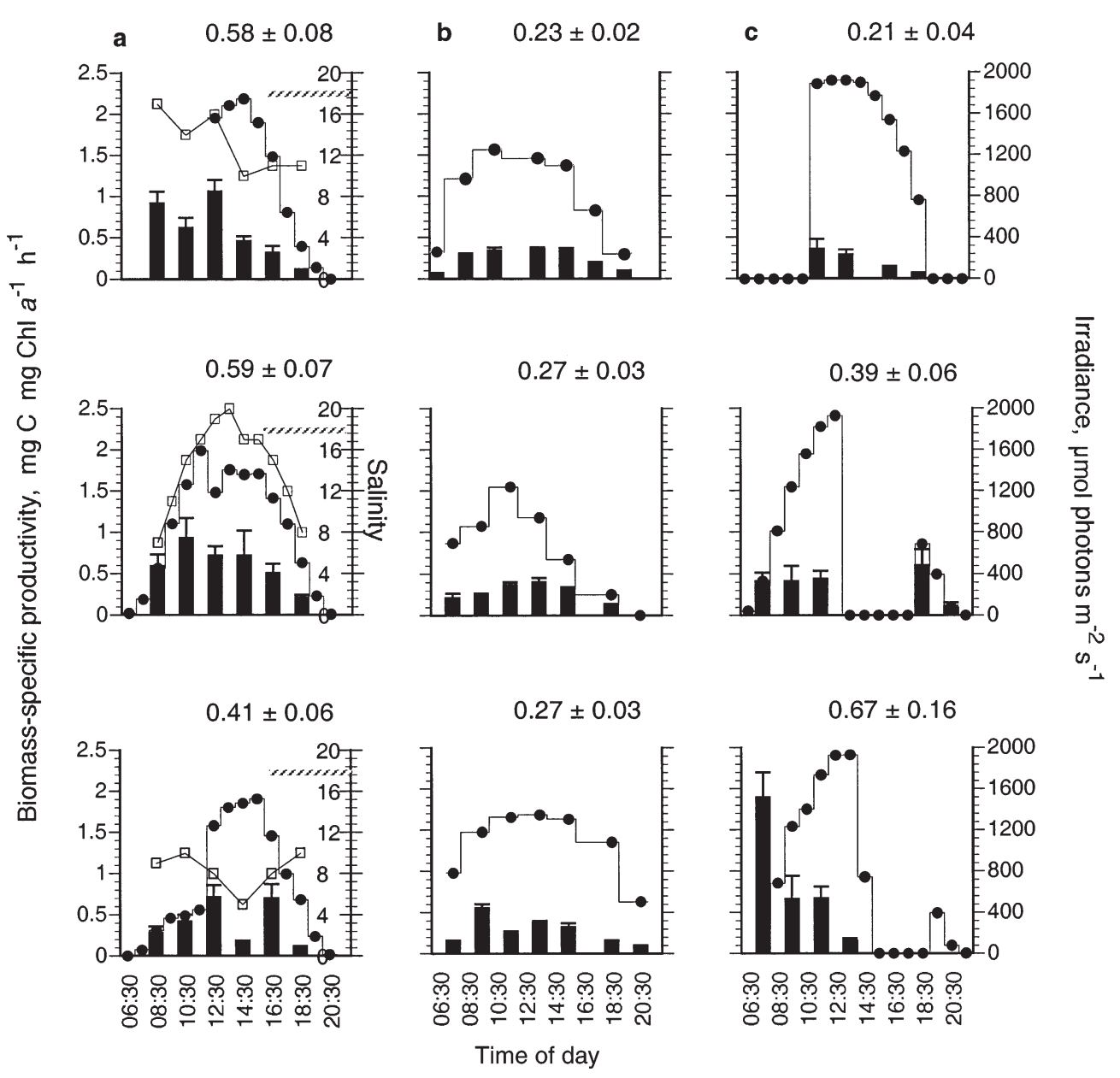

Fig. 3. Biomass-specific primary productivity at (a) Giralda, (b) Vallda, and (c) Sarilhos Pequenos; days (see Fig. 1 legend) are shown in chronological order from top to bottom. Bars: $\pm \mathrm{SE}$ for each incubation period $(\mathrm{n}=4$ to 5); values: means $\pm \mathrm{SE}$ averaged over each day ( $\mathrm{n}=20$ to 35). Right-hand ordinate: irradiance (•) in air for Giralda (a) and at sediment surface for Vallda (b) and Sarilhos Pequenos (c). Salinity of overlying water at Giralda is also shown ()

in the morning (up to and including the 12:00 to 13:00 $\mathrm{h}$ block), when high incident irradiance tended to combine with a shallow, clear water column (Fig. 2a).

Vallda, Sweden: subtidal site, little tidal influence

Unlike at the Italian site, the water column remained clear throughout the tidal cycle. Salinity ranged from 20 to 24 and temperature of the sediment from 14 to $22^{\circ} \mathrm{C}$, following air temperature.

Mean chl a concentrations ranged from 35 to $59 \mathrm{mg}$ $\mathrm{m}^{-2}$ (Fig. 1b). Only on the final day (26 August) was there a significant difference between times within a day ( $p=0.0152$ ). This resulted from a significantly lower concentration measured in the second time block (SNK, p < 0.05). Mean daily concentrations of chl $a$ were significantly different between days ( $\mathrm{p}=$ 0.0003) (Fig. 1b).
On all $3 \mathrm{~d}$, there was a significant difference with time for both $P(p<0.0003)$ and $P^{B}(p=0.0001)$ resulting from the lower early-morning and late-evening rates (Figs. 2b \& 3b, respectively). There were no significant differences between days for $\mathrm{P}_{\mathrm{D}}$ and $\mathrm{P}_{\mathrm{D}}^{\mathrm{B}}$ (biomass-specific productivity averaged over the day). Summing production over the daylight period for the 3 d gave 154, 172 and $164 \mathrm{mg} \mathrm{C} \mathrm{m}^{-2} \mathrm{~d}^{-1}$ for 19, 24 and 26 August, respectively.

\section{Sarilhos Pequenos, Portugal: intertidal site}

Primary productivity was measured only when the sediment was air-exposed, as because of the turbid water column it was assumed that no benthic productivity could occur during the immersion period. As the tides moved from neaps to springs, daytime exposure periods changed, and therefore 1 block of $8.2 \mathrm{~h}, 2$ blocks of 
6.5 and $3.5 \mathrm{~h}$ and 2 blocks of 7.5 and $2 \mathrm{~h}$ were used for measurements (Figs. 1c, 2c \& 3c). Sediment temperature ranged from 20 to $28^{\circ} \mathrm{C}$ during the measurement periods, with salinity varying between 24 and 57 (M. Bartoli pers. comm.) in the surface interstitial water. Water content of the surface $3 \mathrm{~mm}$ of sediment did not vary significantly over the emersion period $(p>0.05)$.

Mean chl a ranged from 11 to $94 \mathrm{mg} \mathrm{m}^{-2}$ (Fig. 1c). Although no difference ( $p=0.26, n=25)$ was found in the spatial variation of chl a when investigated prior to the study, highly significant differences were found with time, both within ( $p=0.0001$ for all days) and between ( $p=0.0017)$ days (see 'Discussion: Variation between sites'). On 17 June, mean chl a increased steeply in the surface $3 \mathrm{~mm}$ of sediment

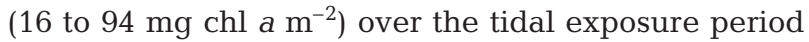
(Fig. 1c); however, this pattern was not repeated during the following measurement periods.

Daily production increased from 17 to 25 June (50, 97 and $138 \mathrm{mg} \mathrm{C} \mathrm{m}^{-2} \mathrm{~d}^{-1}$ for 17, 23 and 25 June, (respectively). $\mathrm{P}_{\mathrm{D}}^{\mathrm{B}}$ also increased significantly over the $3 \mathrm{~d}$ from 0.2 to $0.7 \mathrm{mg} \mathrm{C} \mathrm{mg}^{-1} \mathrm{chl} \mathrm{a} \mathrm{h}^{-1}$ (Fig. 3c). However, no consistent pattern of $\mathrm{P}$ and $\mathrm{P}^{\mathrm{B}}$ across the exposure period could be established.

\section{Differences between sites}

Table 2 shows the results considered on a site basis. The sediments at Giralda were generally sandier than those at Vallda, while the site at Sarilhos Pequenos was composed of the fine cohesive sediments that are typical of intertidal mudflats. The diel pattern of primary productivity varied between sites (Figs. 2 \& 3). The subtidal Vallda site displayed the most simplistic diel pattern of the 3 sites studied, with microphytobenthic productivity following the pattern of incident irradiance (see Fig. 4).

A comparable range of irradiance and number of daylight hours was observed for all the sites (Table 2). Mean hourly productivity was greatest for the Italian site $\left(17 \mathrm{mg} \mathrm{C} \mathrm{m} \mathrm{m}^{-2} \mathrm{~h}^{-1}\right.$ ) and significantly higher $(\mathrm{p}=$ $0.0024)$ than the mean rates at Vallda $\left(12 \mathrm{mg} \mathrm{C} \mathrm{m}^{-2} \mathrm{~h}^{-1}\right)$ and Sarilhos Pequenos (11 $\mathrm{mg} \mathrm{C} \mathrm{m}^{-2} \mathrm{~h}^{-1}$ ). Biomass-specific productivity also proved significantly different between sites $(p=0.0001$ ) (Table 2$)$. Although the daily productivity appeared to vary between sites, no significant difference in daily production was found between the sites $(p=0.102)$ over the $3 d$. This was probably due the high variation within a site for Giralda (coefficient of variation, $\mathrm{CV}=39 \%$ ) and Sarilhos Pequenos (CV $=46 \%$ ) (Table 2).

Despite significant differences in the microphytobenthic biomass between sites ( $p=0.0001)$, with Vallda having a higher mean biomass than the other 2 sites, the mean chl a concentrations were of similar magnitude (Table 2). However, the range of chl a was greater at the intertidal site $(\mathrm{CV}=74 \%)$ compared to Giralda $(\mathrm{CV}=37 \%)$ and Vallda $(\mathrm{CV}=22 \%)$.

The composition of the microphytobenthic community also varied between sites. The fine intertidal sediments were dominated by the epipelic diatom Navicula phyllepta Kützing (80\%), with the total count being comprised of only 7 forms. The diversity at the subtidal sites appeared higher, with approx. 40 forms being found in both the counts for Giralda and Vallda. These were dominated by small epipsammic, naviculoid diatoms (not shown, but in Sundbäck et al. 1998). The dominating species at Giralda and Vallda comprised $<30 \%$ of the total.

\section{In situ productivity versus ambient irradiance}

Although it was not the intention of this study to define the photosynthetic characteristics of the microphytobenthic communities, it was considered of ecological interest to examine the relationship of the in 


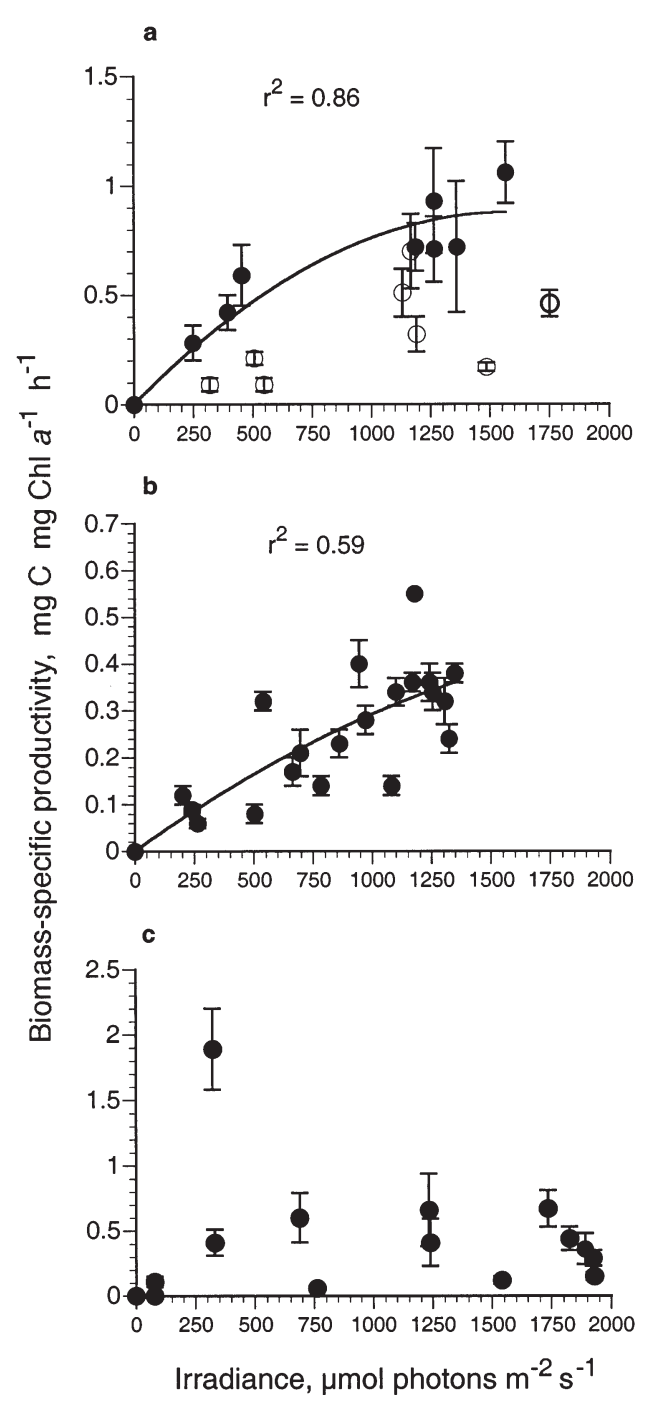

Fig. 4. Relationships of in situ biomass-specific productivity to incident irradiance for (a) Giralda, (b) Vallda, and (c) Sarilhos Pequenos. Irradiance data at Giralda is from air, with data points split into measurements when water column appeared clear $(\bullet)$ and when there was obvious suspended matter in water (O). No statistically significant curve could be fitted for Sarilhos Pequenos. Note that ordinate scales vary

situ biomass-normalised productivity to ambient irradiance at each site. The relationship varied between the sites. Statistically significant relationships were found for both the subtidal sites when data for the Giralda site were limited to clear-water periods only (Fig. 4a,b). The relationship between in situ productivity and irradiance at Sarilhos Pequenos proved so variable, differing within and between days, that no curve fit could be determined (Fig. 4c).

Although the irradiance data at Giralda has to be considered as an overestimation of irradiance at the sediment surface, the pattern of increased productivity with increased irradiance under clear-water conditions is still applicable. Calculation of irradiance at the sediment surface at Vallda reduced values by approx. $20 \%$ of air irradiance but did not alter the shape of the curve. There was no sign of photosaturation of the in situ sediment microalgal community at Vallda $(<1760 \mu \mathrm{mol}$ photons $\mathrm{m}^{-2} \mathrm{~s}^{-1}$ ), but an apparent approaching of photosaturation was seen at Giralda (Fig. 4a).

\section{DISCUSSION}

By employing principally the same methods at all 3 sites, it has been possible to investigate the patterns of productivity at sites exposed to different tidal regimes. Although the study includes no replication of the site type (an obvious weakness if directly comparing tidal regimes), measurements were replicated in time. Besides spatial variation, previous studies have generally focused on short-scale, hour-to-hour variation (e.g. Pinckney \& Zingmark 1991, Blanchard \& Cariou-Le Gall 1994) or long-term variation, seasonal or between years (e.g. Sundbäck \& Jönsson 1988, Barranguet et al. 1997, Sundbäck et al. 2000). However, often the importance of considering mid-scale (daily) variation has been overlooked (cf. Morrisey et al. 1994). Shaffer \& Onuf (1983) concluded that a reliable estimation of monthly production required measurements to be made several times a month, with studies sampling only once or twice introducing a $40 \%$ error into the monthly productivity estimate. This was reduced to $10 \%$ when sampling increased to $4 \mathrm{~d} \mathrm{mo}^{-1}$. Although our study only considered short- (h) and mid-scale (d) variation, the total number of productivity measurements made at each site were substantial (ca 70 to $100)$, equivalent to that seen in many seasonal studies.

\section{Variation between sites}

It must be kept in mind that our study represents only a 'snap shot' in time from 3 different tidal regimes. However, the level of replication allows some discussion of the patterns emerging from the material. Above all, it was striking that both the biomass and total daily production of the microphytobenthos were of similar magnitude in all 3 areas, despite their different tidal influence, sediment type, nutrient regime (Table 2) and diel pattern of primary productivity.

Microphytobenthic biomass and total daily production

The observation that the microphytobenthic biomass varied only slightly between the sites agrees with other previous data sets which increasingly show that esti- 
mates of the magnitude of microphytobenthic biomass from intertidal and shallow subtidal sites can be similar (Table 3 of present paper and tables in Colijn \& de Jonge 1984, MacIntyre et al. 1996). Thus, the idea that sandy sediments generally support significantly lower concentrations of microalgae than muddy sediments (for review see Underwood \& Kromkamp 1999), was not supported by our results, rather the opposite. One explanation for the similarity of the biomass concentration per area could simply be the different thickness of the photic zone in sandy and muddy sediments. The intertidal microphytobenthos, although able to move to the optimal light environment, may well be limited by space within the narrow photic zone $(<500 \mu \mathrm{m})$ during a limited production period. High cell densities in 'bloom' periods may also be regulated by greater losses due to resuspension and grazing by epifauna. The predominantly epipsammic communities may distribute throughout the deeper photic zone found in sandier sediments (ca 3 mm, Kühl et al. 1994) but are unable to move to optimise their environment. The biomasses measured at the 2 subtidal sites in our study appear representative of the sites (for Giralda see Viaroli et al. 1998, for Vallda see Sundbäck et al. 2000), while concentrations at Sarilhos Pequenos fall within the range reported for other intertidal sites in the Tagus estuary (Brotas et al. 1995).

While the magnitude of biomass and productivity was rather similar, the 3 sites differed with regard to the level of intra-site heterogeneity and species composition. The subtidal sites showed less variation in chl $a$ and productivity (Vallda < Giralda) than the intertidal site. The high degree of both spatial and temporal heterogeneity at the intertidal site agrees with the findings of others (e.g. Brotas et al. 1995 and references therein). However, our study was not designed to investigate microalgal heterogeneity between tidal regimes and the results may well be a consequence of sediment type. Sundbäck et al. (2000) found a high degree of variation for a shallow sub-tidal site with fine

Table 3. Ranges of chlorophyll a $\left(\mathrm{mg} \mathrm{m}^{-2}\right)$ reported for muddy and sandy sediments from selection of intertidal and shallow, subtidal $(<5 \mathrm{~m})$ areas. Concentrations were estimated from figures in respective studies. Pigment analysis was carried out by spectrophotometric methods unless otherwise stated. Further chlorophyll estimates are to be found in Colijn \& de Jonge (1984) and MacIntyre et al. (1996)

\begin{tabular}{|c|c|c|c|}
\hline Locality & $\begin{array}{c}\text { Sediment } \\
\text { thickness } \\
(\mathrm{mm})\end{array}$ & $\begin{array}{c}\mathrm{Chl} \mathrm{a} \\
\text { range } \\
\left(\mathrm{mg} \mathrm{m}^{-2}\right)\end{array}$ & Source \\
\hline \multicolumn{4}{|l|}{ Shallow subtidal, sand } \\
\hline Mississippi Coast, USA & 10 & $20-850$ & Daehnick et al. (1992) \\
\hline Delmarva Peninsula, Virginia, USA & 10 & $120-200$ & Reay et al. (1995) \\
\hline Port Phillip Bay, Australia & $10^{\mathrm{a}}$ & $50-250$ & Light \& Beardall (1998) \\
\hline Kattegat, Sweden & 3 & $35-60$ & This study \\
\hline Sacca di Goro, Italy & 3 & $10-50$ & This study \\
\hline \multicolumn{4}{|l|}{ Shallow subtidal, mud } \\
\hline North Inlet Estuary, South Carolina, USA & 2 & $45-80$ & Pinckney \& Zingmark (1993) \\
\hline Thau Lagoon, France & 10 & $50-125$ & Barranguet et al. (1994) \\
\hline Delmarva Peninsula, Virginia, USA & 10 & $80-120$ & Reay et al. (1995) \\
\hline Mobile Bay, Alabama, USA & 5 & $<1-30$ & Schreiber \& Pennock (1995) \\
\hline Carteau Bay, France & 10 & $50-125$ & Barranguet (1997) \\
\hline Kattegat, Sweden & 3 & $20-70$ & Sundbäck et al. (2000) \\
\hline \multicolumn{4}{|l|}{ Intertidal, sand } \\
\hline Sheepscot River Estuary, Maine, USA & 20 & $45-105$ & Cammen (1991) \\
\hline North Inlet Estuary, South Carolina, USA & 2 & $35-70$ & Pinckney \& Zingmark (1993) \\
\hline Tagus Estuary, Portugal & 10 & $40-180$ & Brotas et al. (1995) \\
\hline Westerschelde, SW Netherlands & $1^{\mathrm{b}}$ & $2-15$ & Barranguet et al. (1998) \\
\hline Barnstable Harbor, Massachusetts, USA & 17.6 & $125-392$ & Sandulli \& Pinckney (1999) \\
\hline \multicolumn{4}{|l|}{ Intertidal, mud } \\
\hline Sheepscot River Estuary, Maine, USA & 20 & $25-140$ & Cammen (1991) \\
\hline North Inlet Estuary, South Carolina, USA & 2 & $40-70$ & Pinckney \& Zingmark (1993) \\
\hline Ems-Dollard Estuary, Netherlands & 5 & $29-247$ & de Jonge \& Colijn (1994) \\
\hline Tagus Estuary, Portugal & 10 & $70-260$ & Brotas et al. (1995) \\
\hline Gironde Estuary, France & 10 & $5-120$ & Santos et al. (1997) \\
\hline Westerschelde, SW Netherlands & 1 & $15-31$ & Barranguet et al. (1998) \\
\hline Tagus Estuary, Portugal & 3 & $11-95$ & This study \\
\hline
\end{tabular}


sediments. The difference in species composition was more than likely to have been determined by sediment type. Other studies (e.g. Barranguet 1997) have also found the same magnitudes of biomass from sites of different sediment-sizing, with differences only showing in the composition of the microalgal community.

No significant difference in mean daily productivity between the sites was found. However, mean biomassspecific productivity was significantly lower at Vallda than the other 2 sites, possibly as a result of nutrient limitation ( $\mathrm{N}$ availability in the overlying water differed by 2 orders of magnitude, Vallda $<$ Giralda $\approx$ Sarilhos Pequenos: Table 1). Nutrient limitation has been previously shown for sandy subtidal sediments (Nilsson et al. 1991). On the other hand, the sandy site appears to be highly efficient in internal $\mathrm{N}$ cycling (Sundbäck et al. 2000), which agrees with the findings of Lomstein et al. (1998), the sediment porewater being an important source of remineralised N.

Mean $\mathrm{P}^{\mathrm{B}}$ at the 3 sites was highest at Giralda. However, the greatest range of $\mathrm{P}^{\mathrm{B}}$ was found at Sarilhos Pequenos, with daily values increasing across the days. This variation is likely to have resulted from the pattern of tidal exposure at the site. If the microphytobenthos became limited over the exposure period by, for example, $\mathrm{CO}_{2}$ (Rasmussen et al. 1983, Glud et al. 1992) or nutrients (see below), then the greatest efficiency of the sediment phototrophs would occur when the cells first reached the photic zone of the exposed sediment. This can be seen in the diel patterns of $\mathrm{P}^{\mathrm{B}}$ presented here (Fig. 3c). Rates decreased with time across the tidal exposure. As a result, the highest productivity of the microphytobenthic community, on a daily basis, resulted from a split in the daytime emersion period. On the first sampling day, a single (long) sediment exposure possibly resulted in nutrient limitation of the microphytobenthic community. The addition of ammonium to replicate ${ }^{14} \mathrm{C}$ cores significantly stimulated the uptake of the ${ }^{14} \mathrm{C}$ (Miles et al. unpubl. data) during high irradiance periods, indicating that cells in the surface biofilm may have become nutrientlimited. No stimulation was seen in the evening, however, when in situ irradiance was lower. A few other studies have found evidence of nutrient limitation in emersed intertidal microphytobenthic communities (e.g. Feuillet-Girard et al. 1997, Thornton et al. 1999).

A general interesting finding was that the mean daily production of the muddy tidal site did not exceed that of the subtidal sandy sites (Table 2), but was rather lower. A recent study comparing annual mean daily primary productivity (oxygen flux in intact sediment) of 22 European sites suggests that shallow subtidal sediments in microtidal areas may even support a higher daily primary productivity than intertidal mudflats (Sundbäck et al. unpubl. data), probably because of the shorter daylight exposure at tidal sites compared with constantly submersed clear-water sites.

To conclude, the lack of differences between the sandy subtidal and muddy intertidal sites studied might be explained by (1) a limited daily light period available for primary production on muddy, turbid intertidal sites, (2) a possible short-term limitation of nutrients or carbon in muddy sediments during exposure at low-tide, and (3) an efficient recycling of $\mathrm{N}$ in low-N subtidal sandy areas.

\section{Diel patterns of productivity}

To study the response of microphytobenthic productivity to irradiance (PI), we used our in situ productivity values to investigate whether a general relationship between irradiance and productivity could be established in undisturbed communities in the field under natural varying light conditions. Thus, the curves in Fig. 4 should not be regarded as classical PI curves established under controlled conditions.

The microphytobenthic community at Vallda, covered by only a shallow, clear-water column, followed a clear pattern of carbon uptake driven by incident irradiance. There was no sign of photosaturation of the algal community (Fig. 4b). The 'epipsammic' community dominating these sandy sediments may well have been photoinhibited in the very surface sediments, but this was probably counteracted by the increased production at depth. The good correlation of carbon uptake with irradiance at this site matches that seen for net oxygen production with irradiance over the annual cycle (Sundbäck et al. 2000), indicating that the relationship was not unique for the sampling period.

The driving force behind the production patterns at Giralda was more complex, but it appeared that the varying turbidity (i.e. the freshwater influence) of the overlying water (and hence varying irradiance at the sediment surface) controlled the microphytobenthic productivity. Unlike at Vallda, it appeared that this sediment community approached light-saturation (Fig. 4a).

Patterns at the intertidal site were obviously driven by tidal cycles and the resultant vertical migration of the cells. Pinckney \& Zingmark (1991) found a 2-fold change in gross primary production that they attributed to vertical migration. If measurements are taken over a staggered time frame, as in our case, any relationship between irradiance and productivity is impossible to identify. Even at high irradiances, photoinhibition of the algal community is unlikely, as the motile species are able to position themselves in the optimal light environment. Most previous studies have concluded that the intertidal microphytobenthos does not 
become photoinhibited (Rasmussen et al. 1983, Blanchard \& Cariou-le Gall 1994, Barranguet et al. 1998).

\section{Conclusions}

Microphytobenthic biomass and productivity were 'strikingly' similar in magnitude between the tidal regimes. With the exception of short-term 'blooms' of the microphytobenthos and well-established structural mats, it would therefore appear that coastal shallowwater sediments may have a similar 'carrying capacity' with regard to the general standing microalgal biomass, the main difference being in the degree of heterogeneity within a site and the species composition. As the diel pattern of productivity appears to differ between sites, with local conditions controlling the role of irradiance, a general pattern of microphytobenthic productivity is difficult to determine. Further replication of sites (tidal regimes and sediment types) is required to assess more thoroughly the effect of the tidal regime on microphytobenthic total productivity, but it is apparent that temporal replication on a midscale (i.e. day) basis is important in assessing monthly/seasonal variation.

Acknowledgements. This research has been undertaken in the framework of the NICE project. We acknowledge support from the European Commission's Marine Science and Technology Programme (MAST III) under contract MAS3-CT960048. This is ELOISE contribution no. 145. National funding for the project was received from NUTEK and the Swedish Environmental Protection Agency. We thank Eva Göransson for her extensive field sampling, especially the data from the Vallda site, and Kristin Andreasson for the cell counting. Special thanks to the NICE project group for assistance throughout this study, particularly to the Italian and Portuguese groups for hosting the field campaigns. Light data at Giralda and Sarilhos Pequenos were obtained from Tage Dalsgaard, NERI, Denmark.

\section{LITERATURE CITED}

Ærtebjerg Nielsen G, Bresta AM (1984) Guidelines for the measurements of phytoplankton primary production. Baltic Marine Biologists (Publ. No. 1, 2nd edn), Charlottenlund

Barranguet C (1997) The role of microphytobenthic primary production in a Mediterranean mussel culture area. Estuar Coast Shelf Sci 44:753-765

Barranguet C, Alliot E, Plante-Cuny MP (1994) Benthic microphytic activity at 2 Mediterranean shellfish cultivation sites with reference to benthic fluxes. Oceanol Acta 17: 211-221

Barranguet C, Herman PMJ, Sinke JJ (1997) Microphytobenthos biomass and community composition studied by pigment biomarkers: importance and fate in the carbon cycle of a tidal flat. J Sea Res 38:59-70

Barranguet C, Kromkamp J, Peene J (1998) Factors control- ling primary production and photosynthetic characteristics of intertidal microphytobenthos. Mar Ecol Prog Ser 173:117-126

Bartoli M, Cattadori M, Giordani G, Viaroli P (1996) Benthic oxygen respiration, ammonium and phosphorus regeneration in surficial sediments of the Sacca di Goro (Northern Italy) and two French coastal lagoons: a comparative study. Hydrobiologia 329:143-159

Blanchard GF, Cariou-Le Gall V (1994) Photosynthetic characteristics of microphytobenthos in Marennes-Oléron Bay, France: preliminary results. J Exp Mar Biol Ecol 182:1-14

Brotas V, Catarino F (1995) Microphytobenthos primary production of Tagus estuary intertidal flats (Portugal). Neth J Aquat Ecol 29:333-339

Brotas V, Cabrita T, Portugal A, Serôdio J, Catarino F (1995) Spatio-temporal distribution of microphytobenthic biomass in tidal flats of the Tagus Estuary (Portugal). Hydrobiologia 300/301:93-104

Cammen LM (1991) Annual bacterial production in relation to benthic microalgal production and sediment oxygen uptake in an intertidal sandflat and an intertidal mudflat. Mar Ecol Prog Ser 71:13-25

Colijn F, de Jonge VN (1984) Primary production of microphytobenthos in the Ems-Dollard estuary. Mar Ecol Prog Ser 14:185-196

Daehnick AE, Sullivan MJ, Moncreiff CA (1992) Primary production of the sand microflora in seagrass beds of Mississippi Sound. Bot Mar 35:131-139

Dalsgaard T (1998) Second scientific progress report for nitrogen cycling in estuaries. European Commission (EU MAST Programme MAS3-CT96-0048), Brussels

de Jonge VN, Colijn F(1994) Dynamics of microphytobenthos biomass in the Ems estuary. Mar Ecol Prog Ser 104: 185-196

Feuillet-Girard M, Gouleau D, Blanchard G, Joassard L (1997) Nutrient fluxes on an intertidal mudflat in MarennesOléron Bay, and influence of the emersion period. Aquat Living Resour 10:49-58

Glud RN, Ramsing NB, Revsbech NP (1992) Photosynthesis and photosynthesis-coupled respiration in natural biofilms quantified with oxygen microsensors. J Phycol 28:51-60

Grasshoff K, Erhardt M, Kremling K (1983) Methods of seawater analyses, 2nd edn. Verlag Chemie, Weinheim

Happey-Wood CM, Jones P (1988) Rhythms of vertical migration and motility in intertidal benthic diatoms with particular reference to Pleurosigma angulatum. Diatom Res 3: 83-93

Hartig P, Wolfstein K, Lippemeier S, Colijn F (1998) Photosynthetic activity of natural microphytobenthos populations measured by fluorescence (PAM) and ${ }^{14} \mathrm{C}$-tracer methods: a comparison. Mar Ecol Prog Ser 166:53-62

Jönsson B (1991) A ${ }^{14}$ C-incubation technique for measuring microphytobenthic primary productivity in intact sediment cores. Limnol Oceanogr 36:1485-1492

Kromkamp J, Barranguet C, Peene J (1998) Determination of microphytobenthos PSII quantum efficiency and photosynthetic activity by means of variable chlorophyll fluoresence. Mar Ecol Prog Ser 162:45-55

Kühl M, Lassen C, Jørgensen BB (1994) Light penetration and light intensity in sandy marine sediments measured with irradiance and scalar irradiance fiber-optic microprobes. Mar Ecol Prog Ser 105:139-148

Light B, Beardall J (1998) Distribution and spatial variation of benthic microalgal biomass in a temperate, shallow-water marine system. Aquat Bot 61:39-54

Lomstein BA, Jensen AGU, Hansen JW, Andreasen JB, Hansen LS, Bertsen J, Kunzendorf H (1998) Budgets of 
sediment nitrogen and carbon cycling in the shallow water of Knebel Vig, Denmark. Aquat Microb Ecol 14:69-80

Lorenzen CJ (1967) Determination of chlorophyll and phaeopigments: spectrophotometric equations. Limnol Oceanogr 12:343-346

Lorenzen J, Larsen LH, Kjaer T, Revsbech NP (1998) Biosensor determination of the microscale distribution of nitrate, nitrate assimilation, nitrification, and denitrification in a diatom-inhabited freshwater sediment. Appl Environ Microbiol 64:3264-3269

MacIntyre HL, Geider RJ, Miller DC (1996) Microphytobenthos: the ecological role of the 'secret garden' on unvegetated, shallow-water marine habitats. I. Distribution, abundance and primary production. Estuaries 19:186-201

Morrisey DJ, Underwood AJ, Stark JS, Howitt L (1994) Temporal variation in concentrations of heavy metals in marine sediments. Estuar Coast Shelf Sci 38:271-282

Nilsson P, Jönsson B, Lindström Swanberg I, Sundbäck K (1991) Response of a marine shallow-water sediment system to an increased load of inorganic nutrients. Mar Ecol Prog Ser 71:275-290

Paterson DM (1989) Short-term changes in the erodibility of intertidal cohesive sediments related to the migratory behaviour of epipelic diatoms. Limnol Oceanogr 34: 223-234

Pinckney J, Piceno Y, Lovell CR (1994) Short-term changes in the vertical distribution of benthic microalgal biomass in intertidal muddy sediments. Diatom Res 9:143-153

Pinckney J, Zingmark RG (1991) Effects of tidal stage and sun angles on intertidal benthic microalgal productivity. Mar Ecol Prog Ser 76:81-89

Pinckney J, Zingmark RG (1993) Modeling the annual production of intertidal benthic microalgae in estuarine ecosystems. J Phycol 29:396-407

Rasmussen MB, Henriksen K, Jensen A (1983) Possible causes of temporal fluctuations in primary production of the microphytobenthos in the Danish Wadden Sea. Mar Biol 73:109-114

Reay WG, Gallagher DL, Simmons GM Jr (1995) Sedimentwater column oxygen and nutrient fluxes in nearshore environments of the lower Delmarva Peninsula, USA. Mar Ecol Prog Ser 118:215-227

Revsbech NP, Jørgensen BB (1983) Photosynthesis of benthic microflora measured with high spatial resolution by the oxygen microprofile method: capabilities and limitations of the method. Limnol Oceanogr 28:749-756

Revsbech NP, Nielsen J, Hansen PK (1988) Benthic primary production and oxygen profiles. In: Blackburn TH, Sörensen J (eds) Nitrogen cycling in coastal marine environments. John Wiley \& Sons Ltd, New York, p 69-83

Risgaard-Petersen N, Rysgaard S, Nielsen LP, Revsbech NP (1994) Diurnal variation of denitrification and nitrification in sediments colonized by benthic microphytes. Limnol Oceanogr 39:573-579

Rysgaard S, Christensen PB, Nielsen LP (1995) Seasonal variation in nitrification and denitrification in estuarine sediment colonized by benthic microalgae and bioturbating infauna. Mar Ecol Prog Ser 126:111-121

Editorial responsibility: Otto Kinne (Editor), Oldendorf/Luhe, Germany
Sandulli R, Pinckney J (1999) Patch sizes and spatial patterns of meiobenthic copepods and benthic microalgae in sandy sediments: a microscale approach. J Sea Res 41:179-187

Santos PJP, Castel J, Souza-Santos LP (1997) Spatial distribution and dynamics of microphytobenthos biomass in the Gironde estuary (France). Oceanol Acta 20:549-556

Schreiber RA, Pennock JR (1995) The relative contribution of benthic microalgae to total microalgal production in a shallow sub-tidal estuarine environment. Ophelia 42: 335-352

Serôdio J (1999) Modelling the primary productivity of intertidal microphytobenthos. Role of migratory rhythms studied by in vivo chlorophyll a fluorometry. $\mathrm{PhD}$ thesis, Faculdade de Ciências da Universidade de Lisboa, Lisbon

Serôdio J, da Silva JM, Catarino F (1997) Nondestructive tracing of migratory rhythms of intertidal benthic microalgae using in vivo chlorophyll a fluorescence. J Phycol 33: $533-542$

Shaffer GP, Onuf CP (1983) An analysis of factors influencing the primary production of the benthic microflora in a southern California lagoon. Neth J Sea Res 17:126-144

Shaffer GP, Onuf CP (1985) Reducing the error in estimating annual production of benthic microflora: hourly to monthly rates, patchiness in space and time. Mar Ecol Prog Ser 26:221-231

Sundbäck K, Jönsson B (1988) Microphytobenthic productivity and biomass in sublittoral sediments of a stratified bay, southeastern Kattegat. J Exp Mar Biol Ecol 122:63-81

Sundbäck K, Nilsson P, Nilsson C, Jönsson B (1996) Balance between autotrophic and heterotrophic components and processes in the sandy sediments: a field study. Estuar Coast Shelf Sci 43:689-706

Sundbäck K, Miles A, Goransson E (1998) Microtidal waters in Northern Europe. Effects of benthic microalgae. In: Dalsgaard $\mathrm{T}$ (ed) Second scientific progress report for nitrogen cycling in estuaries. European Commission (EU MAST Programme MAS3-CT96-0048), Brussels, p 40-54

Sundbäck K, Miles A, Goransson E (2000) Nitrogen fluxes, denitrification and the role microphytobenthos in microtidal shallow-water sediments: an annual study. Mar Ecol Prog Ser 200:59-76

Sutherland TF, Grant J, Amos CL (1998) The effect of carbohydrate production by the diatom Nitzschia curvilineata. Limnol Oceanogr 43:65-72

Thorton DCO, Underwood GJC, Nedwell DB (1999) Effect of illumination and emersion period on the exchange of ammonium across the estuarine sediment-water interface. Mar Ecol Prog Ser 184:21-29

Underwood AJ (1997) Experiments in ecology. Cambridge University Press, Cambridge

Underwood GJC, Kromkamp J (1999) Primary production by phytoplankton and microphytobenthos in estuaries. Adv Ecol Res 29:93-153

Viaroli P, Bartoli M, Welsh D (1998) Microtidal waters in Southern Europe. Effects of benthic microalgae. In: Dalsgaard T (ed) Second scientific progress report for nitrogen cycling in estuaries. European Commission (EU MAST Programme MAS3-CT96-0048), Brussels, p 75-89

Submitted: August 30, 1999; Accepted: April 4, 2000

Proofs received from author(s): September 29, 2000 